\title{
Mycobacterium hodleri sp. nov., a New Member of the Fast-Growing Mycobacteria Capable of Degrading Polycyclic Aromatic Hydrocarbons
}

\author{
M. KLEESPIES, ${ }^{1}$ R. M. KROPPENSTEDT, ${ }^{2}$ F. A. RAINEY, ${ }^{2}$ L. E. WEBB, ${ }^{1}$ AND E. STACKEBRANDT ${ }^{2 *}$ \\ IBT3, Forschungszentrum Jülich $\mathrm{GmbH}, 52425$ Jülich, ${ }^{1}$ and DSMZ-Deutsche Sammlung von \\ Mikroorganismen und Zellkulturen GmbH, 38124 Braunschweig, ${ }^{2}$ Germany
}

\begin{abstract}
A bacterial strain isolated from a fluoranthene-polluted soil was characterized with respect to its metabolic and chemotaxonomic properties, and its phylogenetic position was determined. This bacterium exhibits all of the genus-specific properties of the genus Mycobacterium and clusters phylogenetically with the group of fast-growing mycobacteria. On the basis of its unique fatty acid pattern, the distinctness of its physiological properties and the uniqueness of the primary structure of its $16 \mathrm{~S}$ ribosomal DNA, we propose that the new isolate should be assigned to a new species, Mycobacterium hodleri. This novel species is phylogenetically closely related to Mycobacterium diernhoferi and Mycobacterium neoaurum. The type strain of $M$. hodleri is strain EMI 2 (= DSM 44183).
\end{abstract}

Members of the genera Rhodococcus (5) and Mycobacterium $(8,13)$ have been reported to be degraders of environmentally hazardous chemicals, including volatile aliphatic hydrocarbons and polyaromatic and chlorinated hydrocarbons. The members of these genera that are known to degrade one or more of these hazardous chemicals include Mycobacterium aurum (7) (which degrades vinyl chloride), Mycobacterium chlorophenolicum (6) (which degrades pentachlorophenol and other polychlorinated phenolic compounds), and Rhodococcus rhodochrous (24) (which degrades vinyl chloride, trichloroethylene and cis-1,2-dichloroethylene). Other Rhodococcus strains that mineralize vinyl chloride and trichloroethylene have been characterized (24). Mycobacterium sp. strain PYR-1 (= DSM 7251 ) has been thoroughly investigated ( 8 ) and has been found to degrade polycyclic aromatic hydrocarbons (PAHs) with up to four ring systems, including fluoranthene (13). On the basis of its physiological properties this strain has been found to be moderately closely related to Mycobacterium austroafricanum (30). As determined by $16 \mathrm{~S}$ ribosomal DNA (rDNA) analysis, this strain clustered with Mycobacterium vaccae and Mycobacterium aurum $(33,39)$, but the $16 \mathrm{~S}$ rDNA sequence of $M$. austroafricanum was not available for comparison. Mycobacterium sp. strains BB1 (= DSM 9487) (37) and PAH135 (39) are other PAH-metabolizing organisms (36) which are phylogenetically related to the cluster containing the rapidly growing mycobacteria; these strains are related to Mycobacterium gilvum (33) and Mycobacterium aichiense (39), respectively. In this paper we describe a new fluoranthene-degrading, rapidly growing isolate that represents a new Mycobacterium species in the Mycobacterium diernhoferi-Mycobacterium neoaurum cluster.

\section{MATERIALS AND METHODS}

Isolation. Strain EMI ${ }^{\mathrm{T}}$ ( $\mathrm{T}=$ type strain) was isolated from soil contaminated with fluoranthene and benzo(a)pyrene. A 5-g portion of soil was incubated in mineral medium ( $\mathrm{pH} 7.0$ ) containing (per liter) $300 \mathrm{mg}$ of $\left(\mathrm{NH}_{4}\right)_{2} \mathrm{HPO}_{4}, 150 \mathrm{mg}$ of $\mathrm{KH}_{2} \mathrm{PO}_{4}, 20 \mathrm{mg}$ of $\mathrm{MgSO}_{4}, 0.1 \mathrm{ml}$ of a $1 \% \mathrm{FeCl}_{3} \cdot 6 \mathrm{H}_{2} \mathrm{O}$ solution, $1 \mathrm{ml}$ of a trace element solution, medium $27(3)$, and $2 \%$ (vol/vol) rapeseed oil. Fluoran-

* Corresponding author. Mailing address: DSMZ-Deutsche Sammlung von Mikroorganismen und Zellkulturen $\mathrm{GmbH}$, Mascheroder Weg 1b, 38124 Braunschweig, Germany. Phone: 495312616 352. Fax: 495312616418 . Electronic mail address: erko@gbf-braunschweig.de. thene was added to the medium at a concentration of $50 \mathrm{mg} \mathrm{liter}{ }^{-1}$. The preparation was incubated with shaking for 28 days at $20^{\circ} \mathrm{C}$. Subcultures were obtained by transferring $0.5-\mathrm{ml}$ portions of the broth into $50-\mathrm{ml}$ portions of the mineral medium containing $50 \mathrm{mg}$ of fluoranthene per liter. Growth was detected after 2 weeks by observing the increase in the turbidity of the medium. Subsequent conventional isolation by dilution and transfer of single colonies onto solidified mineral medium containing $50 \mathrm{mg}$ of fluoranthene per liter and $5 \mathrm{ml}$ of Tween 80 per liter resulted in the recovery of a single isolate that was maintained by weekly transfer to mineral medium containing $50 \mathrm{mg}$ of fluoranthene per liter.

Characterization of strain EMI2 ${ }^{\mathrm{T}}$. Micromorphological properties were determined by phase-contrast microscopy. Gram staining, acid-alcohol fastness, colony morphology, the ability to grow at various temperatures $(15,18,25,28,37$, 42 , and $45^{\circ} \mathrm{C}$ ), pigment production, and photoreactivity were determined after 2 weeks of growth in Middlebrook 7H10 medium and on Trypticase soy broth agar supplemented with Tween 80 by using the proposed minimal standards for the genus Mycobacterium (21). All tests were carried out at $28^{\circ} \mathrm{C}$. The catalase test was performed as described by Kubica and Pool (18). Nitrate reductase and Tween 80 hydrolysis were detected as described by Bönicke (1). The protocols used to determine growth on xylose, trehalose, mannitol, and sorbitol as sole sources of carbon were the protocols described by Silcox et al. (34). Additional carbon source utilization tests and qualitative enzyme assays were performed in standard microtiter plates (F-Forms; Greiner, Nürtingen, Germany) as described previously $(11,12)$ by using modifications described by Kirchof et al. (14) and Klatte et al. (15).

Cooxidation of fluoranthene and a second $\mathrm{PAH}$ (anthracene, pyrene, or phenanthrene) was tested over a period of 7 days by using the liquid mineral medium described above supplemented with $50 \mathrm{mg}$ of each compound per liter. The degradation products were determined by high-performance liquid chromatography (HPLC) by using an acetonitrile- $\mathrm{H}_{3} \mathrm{PO}_{4}$ gradient that consisted of $20 \%$ (vol/vol) acetonitrile and $80 \%$ (vol $/ \mathrm{vol}$ ) $\mathrm{H}_{3} \mathrm{PO}_{4}$ at zero time, $80 \%$ (vol/vol) ace tonitrile and $20 \%$ (vol/vol) $\mathrm{H}_{3} \mathrm{PO}_{4}$ at $20 \mathrm{~min}$, and $20 \%$ (vol/vol) acetonitrile and $80 \%$ (vol/vol) $\mathrm{H}_{3} \mathrm{PO}_{4}$ at $21 \mathrm{~min}$; the flow rate was $1.0 \mathrm{ml} \mathrm{min}{ }^{-1}$. The concentration of fluoranthene was determined by using $85 \%$ (vol/vol) acetonitrile and $15 \%$ ( $\mathrm{vol} / \mathrm{vol}$ ) $\mathrm{H}_{3} \mathrm{PO}_{4}$ at a flow rate of $1.0 \mathrm{ml} \mathrm{min}{ }^{-1}$.

Determination of chemotaxonomic properties. For chemical analyses the isolate was grown in liquid ISP medium 2 containing (per liter) $4 \mathrm{~g}$ of dextrose, $4 \mathrm{~g}$ of yeast extract, and $10 \mathrm{~g}$ of malt extract ( $\mathrm{pH} \mathrm{7.2)}$ for 5 days at $28^{\circ} \mathrm{C}$, harvested by centrifugation, washed, and freeze-dried. The $\mathrm{G}+\mathrm{C}$ content of the DNA was determined by HPLC (25).

Analysis of cell wall diamino acids. An amino acid analysis of whole-cell hydrolysates was performed by using previously described procedures (36).

Extraction and analysis of isoprenoid quinones. Isoprenoid quinones were extracted and purified by using the small-scale integrated procedure of Minnikin et al. (28). Dried preparations were dissolved in $200 \mu \mathrm{l}$ of isopropanol, and 1- to 10- $\mu$ l portions were separated by HPLC without further purification. The menaquinones were separated by HPLC on a Lichrosorb (Merck) RP-18, 5- $\mu \mathrm{m}$ column at $40^{\circ} \mathrm{C}$ by using acetonitrile-isopropanol $(65: 35, \mathrm{vol} / \mathrm{vol})$ as the solvent (17) and on a silver-loaded ion-exchange Nucleosil (Macherey \& Nagel, Düren, Germany) $\mathrm{SAB}, 5-\mu \mathrm{m}$ column at $50^{\circ} \mathrm{C}$ by using $100 \%$ methanol as the solvent (16).

Fatty acid analysis. For fatty acid analyses cells were grown on Middlebrook $7 \mathrm{H} 10$ medium enriched with Middlebrook OADC in petri dishes for 5 days at 
TABLE 1. Physiological properties of isolate $\mathrm{EMI} 2^{\mathrm{T}}$

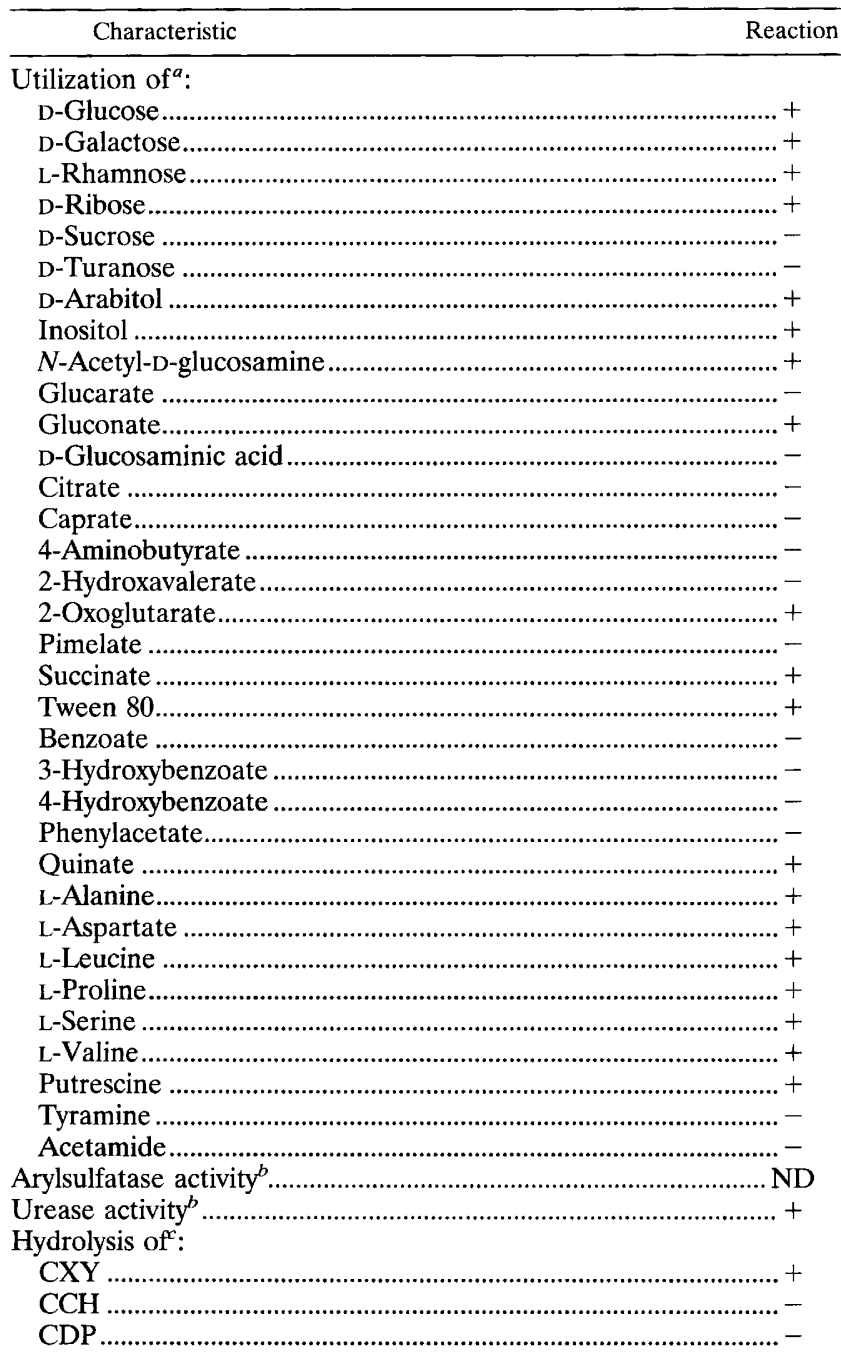

${ }^{a}$ Utilization was determined by the MTT (14) reduction method.

${ }^{b}$ Enzymatic activity was detected by examining the hydrolysis of chromogenic substrates. ND, not detected.

${ }^{c}$ Abbreviations: CXY, $p$-nitrophenyl- $\beta$-D-xyloside; $\mathrm{CCH}, p$-nitrophenylphosphoryl-choline; CDP, 2-deoxythymidine-5'-p-nitrophenylphosphate. $28^{\circ} \mathrm{C}$. Fatty acid methyl esters were prepared from $40 \mathrm{mg}$ (wet weight) of cells as described previously (26), with minor modifications (19). The analyses were performed by using a model $5898 \mathrm{~A}$ gas chromatograph (Hewlett-Packard Co.) connected to a 486 Vectra computer (Hewlett-Packard Co.). The Microbial Identification System software (Microbial ID, Newark, Del.) was used to control the system and to identify the fatty acids. The Microbial Identification System Library for mycobacteria was used to identify the mycobacterium on the basis of its fatty acids.

Extraction and analysis of mycolic acids. The mycolic acids of $50 \mathrm{mg}$ of freeze-dried bacteria were analyzed as described previously $(22,27)$.

Analysis of 16S rDNA. Extraction of genomic DNAs and amplification of the $16 \mathrm{~S}$ rDNAs of strain EMI2 ${ }^{\mathrm{T}}, M$. austroafricanum ATCC $33464^{\mathrm{T}}$, and Mycobacterium parafortuitum DSM $43528^{\mathrm{T}}$ were carried out as described previously (31). PCR products were sequenced directly by using a Taq DyeDeoxy terminator cycle sequencing kit (Applied Biosystems, Foster City, Calif.) and the manufacturer's protocol. The sequence reaction mixtures were electrophoresed by using an Applied Biosystems model 373A DNA sequencer.

Phylogenetic analysis. The 16 S rDNA sequences which we determined were compared with $16 \mathrm{~S}$ rDNA database for members of the order Actinomycetales consisting of the sequences deposited in the Ribosomal Database Project database (23). In order to compensate for multiple substitutions at any given site in the sequence, similarity values were corrected by the method of Jukes and Cantor (10). Dendrograms were constructed by the neighbor-joining method (4) and the distance matrix method of De Soete (2) by using the corrected dissimilarity values. To calculate bootstrap values, we analyzed 200 trees.

Nucleotide sequence accession numbers. The sequences of the type strains of $M$. austroafricanum and $M$. parafortuitum and strain EMI $2^{\mathrm{T}}$ have been deposited in the EMBL data library under accession numbers X93182, X93183, and X93184, respectively.

\section{RESULTS AND DISCUSSION}

Morphological properties. Cells of strain EMI2 ${ }^{\mathrm{T}}$ were gram positive, acid-alcohol fast, and nonmotile, did not form spores, and were rod shaped (length, 1.8 to $2.3 \mu \mathrm{m}$; diameter, $1 \mu \mathrm{m}$ ). Some cells occurred in V-forms and in palisades. Good growth was observed on Trypticase soy broth agar supplemented with Tween 80 at $25^{\circ} \mathrm{C}$. No growth was observed at $15^{\circ} \mathrm{C}$ and at temperatures above $37^{\circ} \mathrm{C}$. The colonies were smooth, but some rough colonies were also observed. A fatty acid analysis of two different colonies revealed that these colonies had identical fatty acid patterns. The scotochromogenic colonies were saffron yellow on Middlebrook medium and chrome yellow on Trypticase soy broth agar supplemented with Tween 80 . Growth occurred within 4 or 5 days on both media.

Physiological properties. In mineral medium the aerobic isolate was able to grow on a variety of substrates, including glucose, Tween 80 , and rapeseed oil, and $35 \%\left[3-{ }^{14} \mathrm{C}\right]$ fluoranthene $(32.5 \mu \mathrm{g}$ of fluoranthene per liter) was mineralized to ${ }^{14} \mathrm{CO}_{2}$ over a period of $120 \mathrm{~h}$. A total of 29 metabolites were recognized by HPLC, but only one compound, cis-2,3-dihydroxy-2,3-dihydrofluoranthene, could be identified. In the

TABLE 2. Chemotaxonomic properties that show that strain $\mathrm{EMI}^{\mathrm{T}}$ is a member of the genus Mycobacterium ${ }^{a}$

\begin{tabular}{|c|c|c|c|c|c|c|c|c|}
\hline \multirow{2}{*}{ Taxon } & \multirow{2}{*}{$\begin{array}{l}\text { No. of } \mathrm{C} \text { atoms in } \\
\text { mycolic acids }\end{array}$} & \multirow{2}{*}{$\begin{array}{c}\text { Fatty acid } \\
\text { type }^{b}\end{array}$} & \multirow{2}{*}{$\begin{array}{c}\text { Major } \\
\text { menaquinone }\end{array}$} & \multicolumn{4}{|c|}{ Presence of : } & \multirow{2}{*}{$\begin{array}{c}\mathrm{G}+\mathrm{C} \text { content o } \\
\text { DNA }(\mathrm{mol} \%)\end{array}$} \\
\hline & & & & $\overline{\mathrm{PI}}$ & $\mathrm{PE}$ & TBSA & N-gly MA & \\
\hline Strain EMI2 ${ }^{\mathrm{T}}$ & 80 & 1B & MK-9 $\left(\mathrm{H}_{2}\right)$ & + & + & + & + & 73 \\
\hline Mycobacterium & $60-90$ & $1 \mathrm{~B}$ & MK-9( $\left.\mathrm{H}_{2}\right)$ & + & + & + & + & $70-72$ \\
\hline Tsukamurella & $64-78$ & $1 \mathrm{~B}$ & MK-9 & + & + & + & + & $67-68$ \\
\hline Nocardia & $44-60$ & $1 \mathrm{~B}$ & MK- $8\left(\mathrm{H}_{4 \mathrm{c}}\right)$ & + & + & + & + & $64-72$ \\
\hline Rhodococcus & $34-64$ & $1 \mathrm{~B}$ & MK- $8\left(\mathrm{H}_{2}\right)$ & + & + & + & + & $63-73$ \\
\hline Gordona & $48-66$ & $1 \mathrm{~B}$ & MK- $8\left(\mathrm{H}_{2}\right)$ & + & + & + & + & $63-69$ \\
\hline Dietzia & $34-38$ & $1 \mathrm{~B}$ & MK- $8\left(\mathrm{H}_{2}\right)$ & - & + & + & - & 73 \\
\hline Corynebacterium & $22-36$ & $1 \mathrm{~A}$ & MK- $8\left(\mathrm{H}_{2}\right)$ & + & $-d$ & $-{ }^{e}$ & - & $51-67$ \\
\hline
\end{tabular}

${ }^{a}$ The following properties are present in all taxa: meso-diaminopimelic acid is the diagnostic amino acid in the peptidoglycan, and arabinose and galactose are whole-cell sugars. Data from reference 32

${ }^{b}$ As defined by Kroppenstedt et al. (17)

${ }^{c}$ Abbreviations: PI, phosphatidylinositol; PE, phosphatidylethanolamine; TBSA, tuberculostearic acid (10-methyl-octacecanoic acid); N-gly MA, $N$-glycolyl-muramic acid.

${ }^{d}$ Phosphatidylethanolamine is present in some species (16).

$e$ Tuberculostearic acid is present in some species (16). 
TABLE 3. Mycolic acids and pyrolysis esters of strain EMI2 ${ }^{\mathrm{T}}$ and members of the $M$. parafortuitum group $^{a}$

\begin{tabular}{|c|c|c|c|c|c|c|c|c|c|c|}
\hline \multirow{2}{*}{ Taxon } & \multicolumn{7}{|c|}{ Mycolic acid esters } & \multicolumn{3}{|c|}{$\begin{array}{l}\text { Pyrolysis } \\
\text { esters }\end{array}$} \\
\hline & $\alpha$ & $\alpha^{\prime}$ & $\begin{array}{l}\text { Meth- } \\
\text { oxy }\end{array}$ & Keto & Epoxy & $\begin{array}{l}\text { Wax- } \\
\text { ester }^{b}\end{array}$ & $\omega-1^{c}$ & $\mathrm{C}_{22}$ & $C_{24}$ & $\mathrm{C}_{26}$ \\
\hline Strain EMI $2^{\mathrm{T}}$ & $+^{d}$ & - & - & + & - & + & - & + & + & - \\
\hline M. aurum & + & $(+)$ & - & + & - & + & - & + & + & - \\
\hline M. austroafricanum & + & $(+)$ & - & + & - & + & - & + & - & - \\
\hline M. diernhoferi & + & - & - & + & - & + & - & + & + & - \\
\hline M. neoaurum & + & - & - & + & - & + & - & + & - & - \\
\hline M. parafortuitum & + & + & - & + & - & + & - & + & - & - \\
\hline
\end{tabular}

${ }^{a}$ Data from references 7,9 , and 22 .

${ }^{b}$ Waxesters-mycolates.

${ }^{c} \omega$-1-Methoxymycolates.

${ }^{d}+$, present; - , absent; $(+)$, present only in some strains

presence of fluoranthene strain $\mathrm{EMI} 2^{\mathrm{T}}$ was capable of cooxidizing several PAHs (at a concentration of $50 \mathrm{mg} \mathrm{liter}^{-1}$ ), including phenanthrene ( $86 \%$ reduction), fluorene ( $60 \%$ reduction), pyrene (31\% reduction), and anthracene (20\% reduction); in the presence of these PAHs the concentration of fluoranthene was reduced by $83,98,81$, and $69 \%$, respectively. None of these other PAHs was degraded in the absence of fluoranthene.

The results of carbon source utilization and qualitative enzyme tests are shown in Table 1.

Chemotaxonomic properties. Our analysis of strain EMI2 ${ }^{\mathrm{T}}$ revealed a pattern of chemotaxonomic features that are typical of members of the genus Mycobacterium (Table 2). The cell walls were acid fast and contained meso-diaminopimelic acid as the only diamino acid. The sugars identified in whole-cell hydrolysates were mainly arabinose and galactose; small amounts of ribose and glucose were also found. Our analysis of a wholecell methanolysate by thin-layer chromatography revealed a multispot pattern composed of long-chain alpha-mycolates, keto-mycolates, and two other spots identified as omega-carbomycolates and long-chain alcohols (wax esters). This combination of mycolic acids and the pattern of the pyrolysis products of the mycolic acids are shared by strain EMI $2^{\mathrm{T}}, M$. austroafricanum, $M$. parafortuitum, and $M$. neoaurum (Table 3 ). The predominant isoprenoid quinone was menaquinone $\mathrm{MK}-9\left(\mathrm{H}_{2}\right)$, which accounted for $85 \%$ of the total menaquinones; the remain-

TABLE 4. Whole-cell fatty acid compositions of isolate $\mathrm{EMI} 2^{\mathrm{T}}$ and related species for which data are available

\begin{tabular}{lrcr}
\hline & \multicolumn{3}{c}{ \% of total fatty acids in: } \\
\cline { 2 - 4 } \multicolumn{1}{c}{ Fatty acid } & $\begin{array}{r}\text { Strain } \\
\text { EMI2 }\end{array}$ & $\begin{array}{c}\text { M. diemhofer } \\
\text { DSM } 43524^{\mathrm{T}}\end{array}$ & $\begin{array}{c}\text { M. neoaurum } \\
\text { DSM 44074 }\end{array}$ \\
\hline $\mathrm{C}_{14: 0}$ & 5.74 & 6.23 & 5.72 \\
$\mathrm{C}_{15: 0}$ cis6 & 1.05 & & \\
$\mathrm{C}_{16: 1}$ cis 9 & 1.49 & 2.17 & 3.48 \\
$\mathrm{C}_{16: 1}$ cis 10 & 2.42 & 0.77 & 5.23 \\
$\mathrm{C}_{16: 1}$ & 6.07 & 5.65 & 28.31 \\
$\mathrm{C}_{16: 0}$ & 25.17 & 25.27 & 15.07 \\
$10 \mathrm{Me}-\mathrm{C}_{16: 0}$ & 0.76 & & 30.46 \\
$\mathrm{C}_{18: 0}$ alcohol & 13.93 & 18.00 & 1.96 \\
$\mathrm{C}_{18: 2}$ cis 9 & 0.63 & & 5.57 \\
$\mathrm{C}_{18: 1}$ & 20.27 & 20.57 & 1.74 \\
$\mathrm{C}_{18: 0}$ & 1.24 & 3.98 & \\
$10 \mathrm{Me}-\mathrm{C}_{18: 0}$ & 18.46 & 11.15 & \\
$\mathrm{C}_{20: 0}$ alcohol & 2.77 & 4.57 & \\
\hline
\end{tabular}

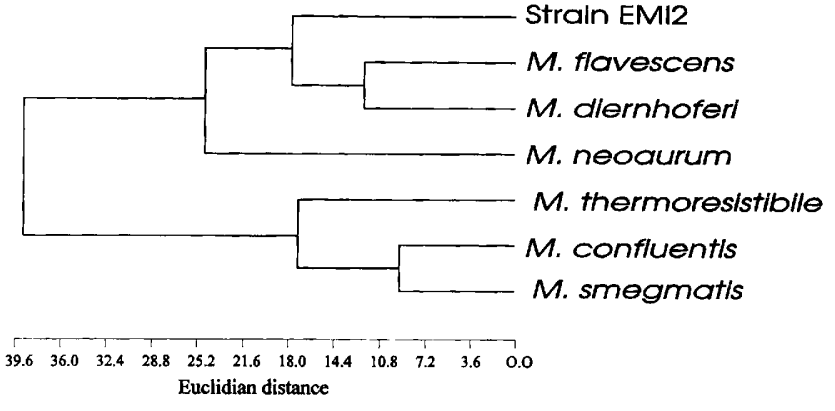

FIG. 1. Dendrogram based on fatty acid profiles showing the relationships between strain EMI $2^{\mathrm{T}}$ and some phylogenetically related Mycobacterium species.

ing $15 \%$ was MK-8 $\left(\mathrm{H}_{2}\right)$. The phospholipid pattern revealed that phosphatidylglycerol, diphosphatidylglycerol, phosphatidylethanolamine, and phosphatidylinositol were present. The $\mathrm{G}+\mathrm{C}$ content of the DNA was $73 \mathrm{~mol} \%$, as determined by the HPLC method. The qualitative and quantitative distributions of the fatty acids are shown in Table 4. Strain EMI $2^{\mathrm{T}}$ contained mainly straight-chain saturated and monounsaturated fatty acids that have chain lengths of 14 to 20 carbon atoms. Substantial amounts of 10-methyl-branched $\mathrm{C}_{18: 0}$ fatty acids $(18.5 \%$ of the total fatty acids) were also found. The occurrence of alcohols with chain lengths of 18 and 20 carbon atoms was a diagnostic feature of strain EMI2 ${ }^{\mathrm{T}}$, and the fatty acid profile of this organism did not match the profile of any other rapidly growing mycobacterium presented in the Microbial Identification System Library for mycobacteria. Figure 1 is a dendrogram based on fatty acid profiles which shows the unique position of strain $\mathrm{EMI} 2^{\mathrm{T}}$ among related organisms.

Phylogenetic analysis. A comparison of the almost complete $16 \mathrm{~S}$ rDNA sequence of isolate EMI2 ${ }^{\mathrm{T}}$ with the sequences of members of the genus Mycobacterium (29) revealed that strain $E M I 2^{\mathrm{T}}$ is a member of the subgroup that contains the fastgrowing mycobacteria. The binary similarity values determined

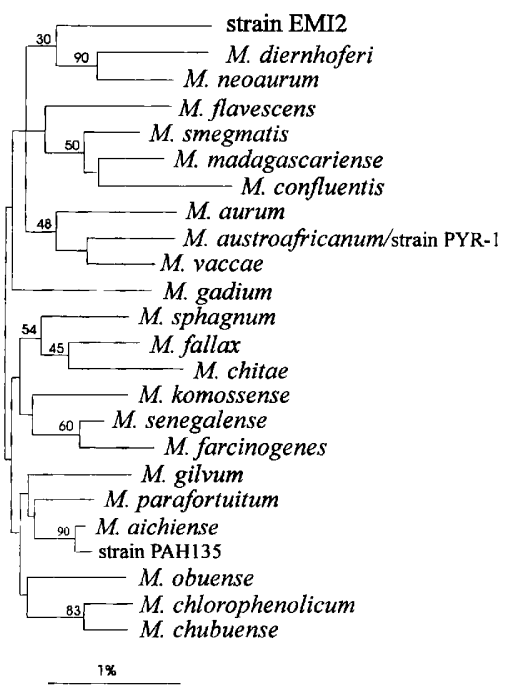

FIG. 2. 16S rDNA relatedness dendrogram showing the phylogenetic position of strain EMI ${ }^{\mathrm{T}}$ within the radiation of rapidly growing mycobacteria. Strain EMI2 is the type strain of $M$. hodleri sp. nov. The dendrogram was generated by using the algorithm of De Soete (2). The numbers are bootstrap values (expressed as percentages); only values greater than $20 \%$ are shown. Bar $=1 \%$ inferred sequence divergence. 
TABLE 5. Physiological properties that distinguish $M$. hodleri from $M$. diernhoferi, $M$. neoaurum, $M$. austroafricanum, and $M$. parafortuitum ${ }^{a}$

\begin{tabular}{|c|c|c|c|c|c|c|c|c|c|c|}
\hline \multirow{2}{*}{ Species } & \multirow{2}{*}{$\begin{array}{l}\text { Formation of } \\
\text { pigment }^{b}\end{array}$} & \multirow{2}{*}{$\begin{array}{l}\text { Growth at } \\
42^{\circ} \mathrm{C}\end{array}$} & \multirow{2}{*}{$\begin{array}{c}\text { Arylsulfatase } \\
\text { activity } \\
\text { (3 days) }\end{array}$} & \multirow{2}{*}{$\begin{array}{l}\text { Tween } 80 \\
\text { hydrolysis }\end{array}$} & \multirow{2}{*}{$\begin{array}{c}\text { Nitrate } \\
\text { reduction }\end{array}$} & \multirow{2}{*}{$\begin{array}{l}\text { Catalase } \\
\text { activity }\end{array}$} & \multicolumn{4}{|c|}{ Utilization of: } \\
\hline & & & & & & & Xylose & Trehalose & Mannitol & Sorbitol \\
\hline M. hodleri & $S$ & $-^{c}$ & ND & + & - & + & + & - & + & + \\
\hline$M$. diemhoferi & $\mathbf{N}$ & - & - & - & + & - & + & - & + & - \\
\hline M. neoaurum & $\mathrm{S}$ & $\mathrm{v}$ & + & $v$ & $\mathrm{v}$ & - & $\mathrm{v}$ & + & + & - \\
\hline M. austroafricanum & S & - & + & $\mathrm{v}$ & + & - & + & - & + & - \\
\hline M. parafortuitum & $\mathrm{P}$ & $\mathrm{v}$ & $\mathrm{v}$ & - & $\mathrm{v}$ & + & $\mathrm{v}$ & - & + & - \\
\hline
\end{tabular}

${ }^{a}$ Data from references 7,20 , and 38 .

${ }^{b} \mathrm{~S}$, scotochromogenic; $\mathrm{N}$, nonchromogenic; $\mathrm{P}$, photochromogenic

$c$-, less than $15 \%$ of the strains are positive; + , more than $85 \%$ of the strains are positive; $v$, variable; ND, not determined.

for strain $\mathrm{EMI} 2^{\mathrm{T}}$ and these organisms range from 96.1 to $97.6 \%$, and the binary similarity values determined for strain $\mathrm{EMI}^{\mathrm{T}}$ and the slowly growing mycobacteria range from 95.0 to $95.8 \%$ (data not shown). Isolate $\mathrm{EMI}^{\mathrm{T}}$ shares with the fast-growing mycobacteria a short helix at positions 451 to 482 (Escherichia coli numbering) $(29,35)$.

Strain EMI2 ${ }^{\mathrm{T}}$ shows the highest levels of $16 \mathrm{~S}$ rDNA similarity with the type strains of Mycobacterium madagascariense (level of similarity, 97.6\%), $M$. neoaurum (97.4\%), and $M$. diernhoferi (97.3\%). Phylogenetic trees based on a distance matrix analysis $(2,4)$ and a maximum-likelihood analysis (4) placed isolate $\mathrm{EMI} 2^{\mathrm{T}}$ with the $M$. diernhoferi-M. neoaurum subcluster. All of the algorithms which we used revealed similar patterns of relatedness among the fast-growing mycobacteria, and these patterns were also similar to the pattern based on the results obtained when the neighborliness method was used (29). According to Tsukamura et al. (38), the following species are members of the $M$. parafortuitum complex: $M$. parafortuitum, $M$. aurum, $M$. neoaurum, $M$. diernhoferi, and $M$. austroafricanum. We found that strain EMI2 ${ }^{\mathrm{T}}$ is not closely related to two of these species, $M$. neoaurum and $M$. diernhoferi (see above), and $M$. aurum appears to be only moderately closely related (Fig. 2). The $16 \mathrm{~S}$ rDNA data also show that $M$. austroafricanum and $M$. parafortuitum are not members of the $M$. diernhoferi-M. neoaurum cluster (Fig. 2). Two strains of PAH-degrading mycobacteria whose $16 \mathrm{~S}$ rDNAs have recently been analyzed (39) are not closely related to strain EMI2 ${ }^{\mathrm{T}}$ (Fig. 2); while strain PAH135 exhibits $96.6 \%$ sequence similarity with the type strain of $M$. aichense, the sequence of strain PYR-1 is identical to the sequence of the type strain of $M$. austroafricanum.

Differentiation of Mycobacterium hodleri sp. nov. from other mycobacteria. The results of our chemotaxonomic and phylogenetic analyses clearly indicate that strain $E M I 2^{\mathrm{T}}$ is a member of a new species of the genus Mycobacterium. The phylogenetic position of this organism is in the subgroup of fast-growing mycobacteria that clusters adjacent to $M$. diernhoferi and $M$. neoaurum. Strain EMI $2^{\mathrm{T}}$ can be distinguished from $M$. diernhoferi by Tween 80 hydrolysis, an absence of nitrate reduction, and utilization of sorbitol. It differs from $M$. neoaurum by its inability to grow at $45^{\circ} \mathrm{C}$, formation of catalase, lack of trehalose utilization, and utilization of sorbitol (Table 5). Strain EMI $2^{\mathrm{T}}$ differs from $M$. austroafricanum in nitrate reduction, catalase activity, and utilization of sorbitol and from $M$. parafortuitum in the mode of pigment production, Tween 80 hydrolysis, and utilization of sorbitol. The most reliable method for determining species affiliation is $16 \mathrm{~S}$ rDNA sequence analysis, which clearly differentiates strain EMI $2^{\mathrm{T}}$ from related species (Fig. 2). The distinct differences (differences of more than $2.5 \%$ ) are located mainly in the variable regions. The name Mycobacterium hodleri sp. nov. is proposed for this novel PAH-degrading organism.
Description of Mycobacterium hodleri sp. nov. Mycobacterium hodleri (hod' le.ri. L.gen. n. hodleri, of Hodler, referring to Christian Hodler, director of the Ministry of Science and Culture of the State of Lower Saxony, Germany, and a strong supporter of natural sciences). Gram positive, acid fast, nonspore forming, nonmotile, and rod shaped (length, 1.8 to 2.3 $\mu \mathrm{m}$; diameter, $1 \mu \mathrm{m}$ ). Some cells occur in V-form and in palisades. Scotochromogenic, producing a saffron yellow pigment on Middlebrook agar and a chrome yellow pigment on Trypticase soy broth agar. Growth occurs at temperatures between 18 and $28^{\circ} \mathrm{C}$. Aerobic and chemoorganotrophic. Catalase positive. Utilizes $N$-acetyl-D-glucosamine, L-alanine, Darabitol, L-aspartate, D-galactose, gluconate, D-glucose, inosotol, L-leucine, 2-oxoglutarate, L-proline, putrescine, quinate, D-ribose, L-rhamnose, L-serine, succinate, and L-valine. Fluoranthene and rapeseed oil are utilized. Capable of cooxidizing fluoranthene with several PAHs, including phenanthrene, fluorene, pyrene, and anthracene. Tween 80 is hydrolyzed.

Acetamide, 4-aminobutyrate, citrate, caprate, D-sucrose, glucarate, D-glucosaminic acid, 3-hydroxybenzoate, 4-hydroxybenzoate, 2-hydroxyvalarate, pimelate, phenylacetate, D-turnanose, and tyramine are not utilized.

Long-chain mycolic acids present. The fatty acids are mainly straight-chain saturated $\left(\mathrm{C}_{14: 0}, \mathrm{C}_{16: 0}\right)$ and monounsaturated $\left(\mathrm{C}_{16: 1}\right.$ cis-10 and $\mathrm{C}_{18: 1}$ cis-9) acids. $\mathrm{C}_{18: 0}$ and $\mathrm{C}_{20: 0}$ alcohols and substantial amounts of tuberculostearic acid (10-methylbranched $\mathrm{C}_{18: 0}$ ) are present. The predominant isoprenoid quinone is menaquinone MK- $9\left(\mathrm{H}_{2}\right)$. The $\mathrm{G}+\mathrm{C}$ content of the DNA is $73 \mathrm{~mol} \%$. Isolated from a fluoranthene-contaminated site near Jülich, Germany. The type strain is strain EMI2, which has been deposited in the DSMZ-Deutsche Sammlung für Mikroorganismen und Zellkulturen GmbH as strain DSM 44183.

\section{ACKNOWLEDGMENTS}

We thank E. Böttger for providing DNAs from $M$. austroafricanum and M. parafortuitum and J. Burghardt, B. Frerichs, and G. Pötter for technical assistance.

\section{REFERENCES}

1. Bönicke, R. 1961. Die Bedeutung der Acylamidasen für die Identifizierung und Differenzierung der verschiedenen Arten der Gattung Mycobacterium. Jahresber. Borstel 5:7-87.

2. De Soete, G. 1983. A least squares algorithm for fitting additive trees to proximity data. Psychometrika 48:621-626.

3. Deutsche Sammlung von Mikroorganismen. 1993. DSM catalogue of strains, 5 th ed. Deutsche Sammlung von Mikroorganismen, Braunschweig, Germany.

4. Felsenstein, J. 1993. PHYLIP (phylogeny inference package), version 3.5c. University of Washington, Seattle.

5. Finnerty, W. R. 1992. The biology and genetics of the genus Rhodococcus. Annu. Rev. Microbiol. 46:193-218.

6. Häggeblom, M. M., L. J. Nohynek, N. J. Palleroni, K. Kronquist, E.-L. Nurmiaho-Lassila, M. S. Salkinoja-Salonen, S. Klatte, and R. Kroppen- 
stedt. 1994. Transfer of polychlorophenol-degrading Rhodococcus chlorophenolicus (Apajalahti et al. 1986) to the genus Mycobacterium as Mycobacterium chlorophenolicum comb. nov. Int. J. Syst. Bacteriol. 44:485-493.

7. Hartmans, S., and J. A. M. deBont. 1992. Aerobic vinyl chloride metabolism in Mycobacterium aurum L1. Appl. Environ. Microbiol. 58:1220-1226.

8. Heitkamp, M. A., and C. E. Cerniglia. 1988. Mineralization of polycyclic aromatic hydrocarbons by a bacterium isolated from sediment below an oil field. Appl. Environ. Microbiol. 54:1612-1614.

9. Hinrikson, H. P., and G. E. Pfyffer. 1994. Mycobacterial mycolic acids. Med. Microbiol. Lett. 3:49-57.

10. Jukes, T. H., and C. R. Cantor. 1969. Evolution of protein molecules, p. 21-132. In $\mathrm{H}$. N. Munro (ed.), Mammalian protein metabolism. Academic Press, New York.

11. Kämpfer, P., W. Dott, and R. M. Kroppenstedt. 1990. Numerical classification and identification of some nocardioform bacteria. J. Gen. Appl. Microbiol. 35:309-331.

12. Kämpfer, P., and R. M. Kroppenstedt. 1994. Enzymatic profiles of Mycobacterium spp. and their value for species differentiation. Microbiology 140: 209-214.

13. Kelley, I., J. P. Freeman, F. E. Evans, and C. E. Cerniglia. 1993. Identification of metabolites from the degradation of fluoranthene by Mycobacterium sp, strain PYR-1. Appl. Environ. Microbiol. 59:800-806.

14. Kirchof, H., C. Maas, M. Runge, B. Franz, R. Schmidt, H. Quentmeier, and P. F. Mühlradt. 1992. Tetrazolium-[3-(4,5-dimethylthiazol-2-yl)-2,5-diphenyltetrazolium bromide] reduction by mycoplasmas. Int. J. Syst. Bacteriol. 42:506-508.

15. Klatte, S., R. M. Kroppenstedt, and F. A. Rainey. 1994. Rhodococcus opacus sp. nov., an unusual nutritionally versatile Rhodococcus species. Syst. Appl. Microbiol. 17:335-360.

16. Kroppenstedt, R. M. 1985. Fatty acid and menaquinone analysis of actinomycetes and related organisms. Soc. Appl. Bacteriol. Tech. Ser. 20:173-199.

17. Kroppenstedt, R. M., F. Korn-Wendisch, V. F. Fowler, and E. Stackebrandt 1981. Biochemical and molecular genetic evidence for transfer of Actinoplanes armeniacus into the family Streptomycetaceae. Zentralbl. Bakteriol. Parasitenkd. Infektionskr. Hyg. Abt. 1 Orig. Reihe C 2:254-262.

18. Kubica, G. P., and G. L. Pool. 1960. Studies on the catalase activity of acid fast bacilli. I. An attempt to subgroup these organisms on the basis of their catalase activities at different temperatures and $\mathrm{pH}$. Am. Rev. Respir. Dis. 81:387-391.

19. Kuykendall, L. D., M. A. Roy, J. J. O'Neill, and T. E. Devine. 1988. Fatty acids, antibiotic resistance, and deoxyribonucleic acid homology groups of Bradyrhizobium japonicum. Int. J. Syst. Bacteriol. 38:358-361.

20. Lefford, M. J. 1980. Mycobacterial culture collection. National Institutes of Health Publication 80-289. U.S. Department of Health and Human Services, Washington, D.C.

21. Levy-Frebault, V. V., and F. Portaels. 1992. Proposed minimal standards for the genus Mycobacterium and for description of new slowly growing Mycobacterium species. Int. J. Syst. Bacteriol. 42:315-323.

22. Luquin, M. V. Ausina, F. Lopez Calahorra, F. Belda, M. Garcia Barcelo, C. Celma, and G. Prats. 1991. Evaluation of practical chromatographic procedures for identification of clinical isolates of mycobacteria. J. Clin. Microbiol. 29:120-130.

23. Maidak, B. L., N. Larsen, M. A. McCaughey, R. Overbeek, G. J. Olsen, K. Fogel, J. Blandy, and C. R. Woese. 1994. The Ribosomal Database Project.
Nucleic Acids Res. 22:3485-3487.

24. Malachowsky, K. J., T. J. Phelps, A. B. Teboli, D. E. Minnikin, and D. C. White. 1994. Aerobic mineralization of trichloroethylene, vinylchloride, and aromatic compounds by Rhodococcus species. Appl. Environ. Microbiol. 60: 542-548.

25. Mesbah, M., U. Premachandran, and W. B. Whitman. 1989. Precise measurement of the $\mathrm{G}+\mathrm{C}$ content of deoxyribonucleic acid by high-performance liquid chromatography. Int. J. Syst. Bacteriol, 39:159-167.

26. Miller, L. T. 1982. A single derivatization method for bacterial fatty acid methyl esters including hydroxy acids. J. Clin. Microbiol. 16:584-586.

27. Minnikin, D. E., I. G. Hutchinson, A. B. Caldicott, and M. Goodfellow. 1980. Thin-layer chromatography of methanolysates of mycolic acid-containing bacteria. J. Chromatogr. 188:221-233.

28. Minnikin, D. E., A. G. O'Donnell, M. Goodfellow, G. Alderson, M. Athalye, K. Schaal, and J. H. Parlett. 1984. An integrated procedure for the extraction of isoprenoid quinones and polar lipids. J. Microbiol. Methods 2:233241.

29. Pitulle, C., M. Dorsch, J. Kazda, J. Wolters, and E. Stackebrandt. 1992. Phylogeny of rapidly growing members of the genus Mycobacterium. Int. J. Syst. Bacteriol. 42:337-343.

30. Rafii, F., W. R. Butler, and C. E. Cerniglia. 1992. Differentiation of rapidly growing, scotochromogenic, polycyclic-aromatic-hydrocarbon metabolizing strains of Mycobacterium sp. from other known Mycobacterium species. Arch. Microbiol. 157:512-520.

31. Rainey, F. A., M. Dorsch, H. W. Morgan, and E. Stackebrandt. 1992. 16S rDNA analysis of Spirochaeta thermophila: its phylogenetic position and implications for the systematics of the order Spirochaetales. Syst. Appl. Microbiol. 15:197-202.

32. Rainey, F. A., S. Klatte, R. M. Kroppenstedt, and E. Stackebrandt. 1995. Dietzia, a new genus including Dietzia maris comb. nov., formerly Rhodococ. cus maris. Int. J. Syst. Bacteriol. 45:32-36.

33. Rainey, F. A., and E. Lang. Unpublished data.

34. Silcox, V. A., R. C. Good, and M. M. Floyd. 1981. Identification of clinically significant Mycobacterium fortuitum complex isolates. J. Clin. Microbiol. 14: 686-691.

35. Stackebrandt, E., and J. Smida. 1988. The phylogeny of the genus $M y c o-$ bacterium as determined by $16 \mathrm{~S}$ rRNA sequences, and development of DNA probes, p. 244-250. In Y. Okami, T. T. Beppu, and H. Ogawara (ed.), Biology of actinomycetes. Japan Scientific Press, Tokyo.

36. Stanek, J. L., and G. D. Roberts. 1974. Simplified approach to identification of aerobic actinomycetes by thin layer chromatography. Appl. Microbiol. 28: 226-231.

37. Tiem, B. A., B. Boldrien, and C. Fritsche. 1993. Degradation of phenanthrene, fluorene fluoranthene, and pyrene by a Mycobacterium species. Appl. Environ. Microbiol. 59:1927-1930.

38. Tsukamura, M., H. van der Meulen, and W. O. K. Grabow. 1983. Numerical taxonomy of rapidly growing, scotochromogenic mycobacteria of the Mycobacterium parafortuitum complex: Mycobacterium austroafricanum sp. nov. and Mycobacterium diemhoferi sp. nov., nom. rev. Int. J. Syst. Bacteriol. 33: $460-469$.

39. Wang, R. F., W. W. Cao, and C. E. Cerniglia. 1995. Phylogenetic analysis of polycyclic aromatic hydrocarbon degrading mycobacteria by $16 \mathrm{~S}$ rRNA sequencing. FEMS Microbiol. Lett. 130:75-80. 